\title{
Environmental impact of cool roof paint: case-study of house retrofit in two hot islands
}

Emmanuel Shittu, Valentina Stojceska, Petra Gratton, Maria Kolokotroni

Brunel University London, Kingston Lane, Uxbridge, UB8 3PH, UK

Corresponding author: Maria Kolokotroni, maria.kolokotroni @brunel.ac.uk

\begin{abstract}
Cool roofs save energy and are particularly suited for low rise buildings in hot climates. This paper presents results of potential energy savings for existing houses in two islands (Sicily and Jamaica) based on validated thermal models. It also presents the lifecycle environmental impact of the cool paint focussing on both the midpoint and endpoint impact categories and compares these with thermal insulation impact. It was found that significant net energy benefits are possible in both locations by a cool roof, more pronounced in Jamaica, which has no heating demand; savings are comparable with thermal insulation reductions. The environmental impact of cool paint is lower than a variety of thermal insulation materials with the exception of water depletion potential. The main hotspots of the cool paint are the production of the polymer followed by the production of the pigment.
\end{abstract}

Keywords: Housing Retrofit, Cool Roof, Thermal Insulation, Life Cycle Assessment, Environmental impact 


\section{Introduction}

The potential benefits of cool roofs in reducing energy demand by buildings and mitigating the urban heat island have been researched vigorously in the last 20 years. Reported results are derived from field measurements, experimental rigs and computational studies. The volume of research papers on cool roofs in Science Direct database with the keyword of 'cool roof' in the title/keyword/abstract have increased from 7 in 1999 to 101 in 2019.

During this time, organisations were created to 'develop accurate and credible methods for evaluating and labeling the solar reflectance and thermal emittance (radiative properties) of roofing products' and to 'disseminate the information to all interested parties' including certification schemes' such as EnergyStar [1, 2]. In many countries, cool roof materials are recommended in the building regulations including retrofits; for example regulations in California [3] contain requirements for the thermal emittance, three-year aged reflectance, and solar reflectance index (SRI) of roofing materials used in new construction and re-roofing projects. In Italy the regulation on energy performance of buildings [4] requires a cost-benefit analysis on the use of cool roofs. In Jamaica solar absorptivity for walls and roofs is specified in thermal energy standard [5].

Energy efficiency benefits of cool roofs have been well documented in the literature and are the focus of recent reviews as well a policy recommendations [6-10]. It has been shown that they are particularly effective in high solar radiation regions where heating is not required [11$14]$ while a heating penalty might be observed in regions with heating requirements $[15,16]$. Results reported in the literature agree that cool roofs are very effective in low rise buildings where the ratio of roof area to surface area of the building is high, in regions with high solar radiation and warm conditions throughout the year so that heating needs are relatively small.

For new buildings, there is a range of available cool roof products (paints, membranes, tiles) that can be used which can be incorporated in the design of the roofing method while in retrofit the choice is determined by the existing roof structure. For residential retrofits the choice is also determined by the cost of the intervention versus energy cost benefits for the occupant/owner. In many cases, a cool paint might be chosen because of easiness of installation and capital cost.

However, what is not clear from the literature is the environmental impact of cool paints. Few studies have reported Life Cycle energy costs $[17,18]$ and comparison of white, coloured, green and PV roofs $[19,20]$ but a full LCA of a purpose manufactured cool paint to include all environmental impact indicators has not been carried out. Such a study would allow better 
comparison with other interventions such as insulation for which some LCA results are available.

Therefore, the main objectives of this study were to use LCA methods to estimate lifecycle environmental impacts of one case-study cool paint applied to two case-study houses in the hot climates of Jamaica (no heating demand) and Sicily (some heating demand) and compare with available data for insulation materials.

Section 2 presents the characteristics of the cool paint and the two case-study houses. Section 3 presents the LCA method and inventory materials while section 4 presents the LCA results for the cool paint for the two locations and comparison with insulation materials sourced from the literature, followed by conclusion in Section 5 .

\section{Description of cool paint and case-study houses}

\subsection{Description of cool paint}

The studied cool paint is a waterborne liquid characterised with 0.84 initial solar reflectance (0.73 after three years of application), 0.90 thermal emittance (0.89 after three years of application), and initial solar reflectance index of 106 (90 after three years of application) [1, 2]. The cool paint comprises of six chemical inputs that are polymers, plasticiser, additives, pigments, solvent and filler. Table 1 presents the details of the six chemical inputs. The polymer is made of Polyurethane (PU) modified acrylic dispersion, which is the main chemical input of the cool paint that provides continuity, holds the distributed pigments and adhesiveness to the applied surface. The second most important is the solvent, which is made of water and glycol ethers. It modifies the viscosity of the cool paint by dissolving or dispersing the polymer. The pigment dispersed in the paint gives its white colour, Ultraviolet (UV) light resistant, weathering, high elasticity and ability to obliterate the flat roof surface after application. The filler gives the cool paint its toughness and abrasiveness. Finally, the additives and plasticiser increase the flexibility of the cool paint [21, 22].

Table 1: Foreground inventory data for the production of cool paint.

\begin{tabular}{|c|c|c|}
\hline Material/chemical input & Value (\%) & Input composition \\
\hline \multirow[t]{2}{*}{ Polymer } & 50 & Acrylic dispersion (70 \%) \\
\hline & & Polyurethane (30%) \\
\hline \multirow[t]{2}{*}{ Solvent } & 20 & Water (80 \%) \\
\hline & & Glycol ethers (20 \%) \\
\hline Filler & 15 & Barite \\
\hline Pigment & 10 & Titanium dioxide \\
\hline Additive & 4 & Zinc dioxide \\
\hline Plasticiser & 1 & Phthalic Anhydride \\
\hline
\end{tabular}




\subsection{Description of case-study houses in Jamaica and Sicily}

Two houses were studied; one located in Portmore, Kingston Jamaica and the second in Palermo Italy. Monthly ambient air temperature and global horizontal solar radiation for of the two locations are shown in Fig. 1. The weather files used are TRY files by Meteonorm [23]. Annual solar radiation is similar for the two locations but distribution over the year differs. Ambient temperature is higher in Portmore throughout the year while in Palermo low ambient temperature during the winter months indicate heating demand for part of the year.

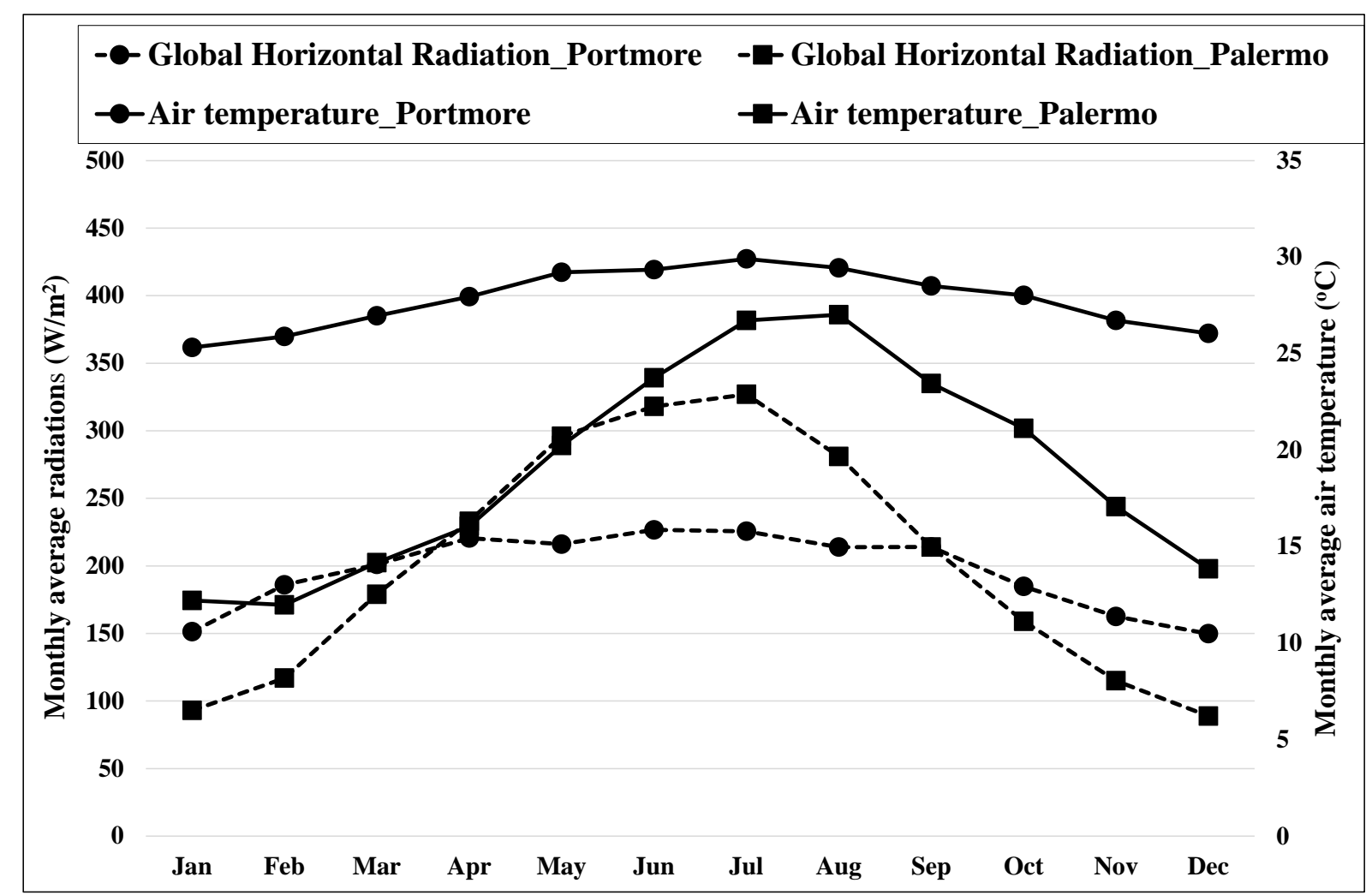

Fig. 1. Monthly average global horizontal solar radiation and air temperature in Portmore, Jamaica and Palermo, Italy.

\subsubsection{Case study house in Portmore, Jamaica}

The case-study house in Portmore was the focus of a previous study reported in [14]. Some details are included in this paper for completeness.

The house is a typical example of low-income single-storey semi-detached houses built in Jamaica. As reported in [14], the roof and internal conditions were measured before and after the installation of the cool paint. The house was modelled using EnergyPlus [24] and simulation results were compared to measurements for verification. Improvement of the indoor thermal 
environment, cooling energy reduction potential and carbon savings by avoiding air conditioning installation were calculated. Measurements indicated that internal ceiling surface temperature was higher before the cool roof application by a maximum of $18.6 \mathrm{~K}$ and an average of $6.8 \mathrm{~K}$. The internal air temperature measurements showed that after applying cool paint, the living room is on an average cooler by $2.3 \mathrm{~K}$. Annual simulations revealed that significant reduction in average temperature throughout the year after the implementation of the cool roof. External roof surface temperature reductions are consistent with solar radiation intensity and correlate with monthly fluctuations. For example, the average external roof surface temperature is reduced by approximately $7 \mathrm{~K}$ with lowest reductions in December/January. Internal ceiling surface temperature reductions also reflect seasonal solar radiation intensity variations by approximately $5.5 \mathrm{~K}$ while internal air temperatures are reduced by $1.2 \mathrm{~K}$. As expected the highest reduction occurs during the hours with high solar radiation intensity. The largest internal ceiling surface temperature reduction was $24.4 \mathrm{~K}$ reduction while the largest external roof surface temperature reduction was $32.4 \mathrm{~K}$. Cooling energy savings were simulated assuming that the house was maintained at $24{ }^{\circ} \mathrm{C}$; the annual potential savings due to cool roof were calculated to $188 \mathrm{kWh} / \mathrm{m}^{2} /$ year. In terms of $\mathrm{CO}_{2}$ emissions reduction, an estimation was carried out assuming a Coefficient of Performance (COP) of 3 for the air-conditioning system and $\mathrm{CO}_{2}$ emission factors from electricity of 0.7961 $\mathrm{kgCO}_{2} / \mathrm{kWh}$ indicating potential savings of $50 \mathrm{kgCO}_{2} / \mathrm{m}^{2} /$ year.

\subsubsection{Case study house in Palermo, Italy}

The second case study house in Palermo, Sicily was chosen to also represent a high solar radiation case but with a distinct heating season so that the energy penalty is explored. The model was developed using the same methodology as described [14]. An EnergyPlus model of the house was developed and calibrated using measurements from the operational house. It was not possible to apply a cool roof paint so the results presented are simulations.

The house is single storey with floor area of $100 \mathrm{~m}^{2}$; it comprises of living room, kitchen, study and three bedrooms. Fig. 2 shows the thermal zones of the house while Table 2 presents its thermal characteristics. The house is naturally ventilated during hot periods of the year (April - October) and heated during cold period (November - March). The natural ventilation is controlled by the occupants who provided the opening schedules. This was simulated using the multi-zone airflow network in EnergyPlus. It was assumed that during the heating period, the house was maintained by a thermostat set point of $20^{\circ} \mathrm{C}$ during occupancy. 
The wind air pressure coefficient data applicable for the case study (low - rise building with flat roof) were obtained from [25].

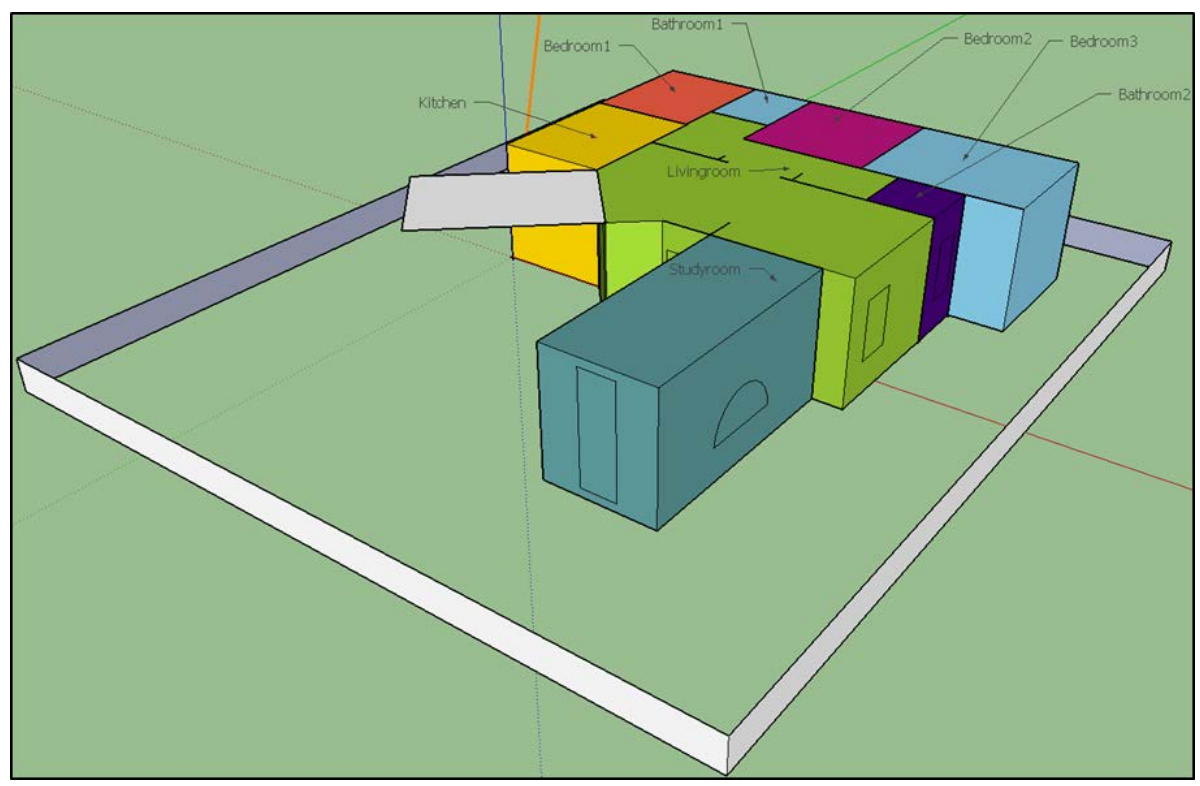

Fig 2. Thermal zones of the Palermo case-study house

Table 2: External fabric and thermal data.

\begin{tabular}{|c|c|c|c|}
\hline \multicolumn{2}{|c|}{ Floor/Roof area $\left(\mathrm{m}^{2}\right)$} & \multicolumn{2}{|l|}{100.4} \\
\hline \multicolumn{2}{|l|}{ Volume $\left(\mathrm{m}^{3}\right)$} & \multicolumn{2}{|l|}{300.2} \\
\hline \multicolumn{2}{|c|}{ External wall area exposed to ambient $\left(\mathrm{m}^{2}\right)$} & \multicolumn{2}{|l|}{117.4} \\
\hline \multicolumn{2}{|c|}{ Window area $\left(\mathrm{m}^{2}\right)-10$ double glazed windows } & \multicolumn{2}{|l|}{15.8} \\
\hline \multicolumn{2}{|c|}{1 North Façade wooden door $\left(\mathrm{m}^{2}\right)$} & \multicolumn{2}{|l|}{2.2} \\
\hline \multicolumn{2}{|c|}{1 North East glass door $\left(\mathrm{m}^{2}\right)$} & \multicolumn{2}{|l|}{3.9} \\
\hline \multicolumn{2}{|c|}{1 Wall double glazed door $\left(\mathrm{m}^{2}\right)$} & \multicolumn{2}{|l|}{1.78} \\
\hline \multicolumn{2}{|l|}{ Occupants } & \multicolumn{2}{|c|}{ 3, at home night and weekends } \\
\hline \multicolumn{2}{|l|}{ Internal heat gains } & \multicolumn{2}{|c|}{$\begin{array}{l}\text { Lighting: } 60 \mathrm{~W}(\mathrm{x} 8) \\
\text { Electric equipment: } 3594 \mathrm{~W}\end{array}$} \\
\hline Building envelop & Material & Thickness (m) & U-Value $\left(\mathrm{W} / \mathrm{m}^{2} \mathrm{~K}\right)$ \\
\hline External walls & $\begin{array}{l}\text { Brick with plaster and } \\
\text { airspace }\end{array}$ & 0.29 & 1.43 \\
\hline Window & Double glazed glass & & 2.753 \\
\hline External door & Wood & 0.05 & 1.97 \\
\hline Roof & $\begin{array}{l}\text { Cast concrete, waterproof } \\
\text { covering and plaster }\end{array}$ & 0.24 & 2.26 \\
\hline Floor & $\begin{array}{l}\text { Cast concrete with floor } \\
\text { vinyl }\end{array}$ & 0.23 & 2.14 \\
\hline
\end{tabular}

Ambient and internal air temperature were measured hourly between January and May 2019 in eight locations inside and one outside using HOBO UX100-003 data loggers with accuracy $\pm 0.21^{\circ} \mathrm{C}$. The external air temperature sensor was placed inside a ventilated shield as used in previous studies [26]. The air temperature results of the model were statistically 
compared (using Mean Bias Error (MBE) equation (Eq. 1) and Coefficient of Variation of the Root Mean Square Error (CVRMSE) equation (Eq. 2)) to the measured inside air temperature for all thermal zones. The MBE and CVRMSE statistical values are presented in Table 3; which are within the recommended MBE and CVRMSE values of less than $\pm 10 \%$ and $30 \%$ respectively relative to the hourly calibrated results [27]. Additionally, Fig 3 presents the correlation of measurements and simulations for the living room and one bedroom. More than $80 \%$ of the points are within the $10 \%$ error.

$$
\begin{aligned}
& M B E=\frac{\sum_{i=1}^{N}\left(M_{i}-S_{i}\right)}{\sum_{i=1}^{N} M_{i}} \\
& C V R M S E=\frac{\sqrt{\sum_{i=1}^{N}\left(M_{i}-S_{i}\right)^{2} / N}}{\bar{M}}
\end{aligned}
$$

where $N$ is the sample data (2952 hours of measured and simulated data) starting at instance, $i=1, M_{i}$ and $S_{i}$ are measured and simulated data, and $\bar{M}$ is the mean of the measured data.

Table 3: MBE and CVRMSE for air temperature

\begin{tabular}{|c|c|c|}
\hline Thermal Zones & MBE & CVRMSE \\
\hline Bathroom 1 & $6.78 \%$ & $9.76 \%$ \\
\hline Bathroom 2 & $3.87 \%$ & $5.47 \%$ \\
\hline Bedroom 1 & $3.95 \%$ & $7.20 \%$ \\
\hline Bedroom 2 & $5.63 \%$ & $8.08 \%$ \\
\hline Bedroom 3 & $5.40 \%$ & $8.21 \%$ \\
\hline Kitchen & $6.28 \%$ & $10.19 \%$ \\
\hline Living room & $3.01 \%$ & $8.20 \%$ \\
\hline Study room & $-3.18 \%$ & $10.36 \%$ \\
\hline
\end{tabular}

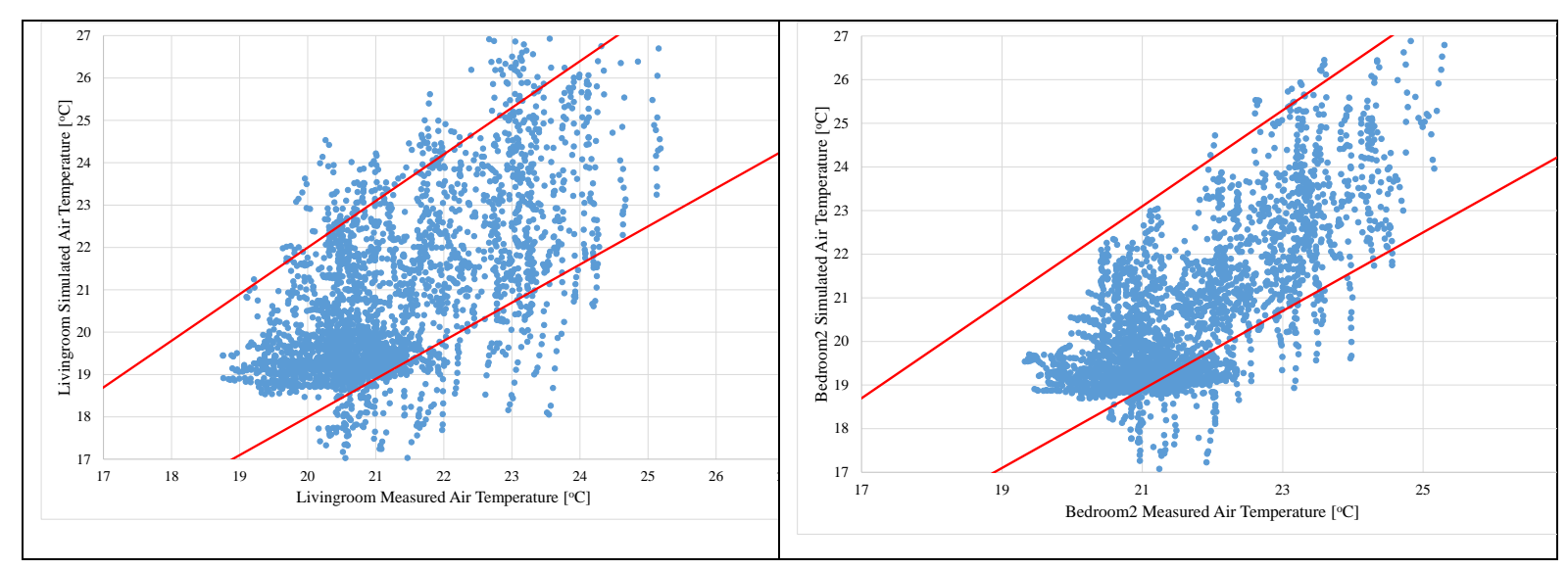

Fig 3. Simulated vs. measured values of internal air temperatures in the living room and one of the bedrooms. 
The application of cool roof has improved thermal comfort in the house as shown in Fig. 4. The same cool paint as for the Portmore case-study was used for the Palermo case-study with initial solar reflectance of 0.82 , thermal emittance of 0.90 and solar reflectivity index of 106 . Average surface temperature of the roof was substantially reduced for every month. This has resulted to a reduction of ceiling surface temperate as well as internal air temperature.



Fig. 4: Reduction of surface and internal air temperature due to the cool roof in the casestudy house in Palermo.

Cooling and heating energy demand were simulated assuming that the house were maintained at $24{ }^{\circ} \mathrm{C}$ in the summer months and $20{ }^{\circ} \mathrm{C}$ in winter during occupancy; the results are shown in Fig. 5 (together with a comparison to insulated roof to be discussed in the next section). As expected heating energy demand has increased after the application of cool roof from 12.7 to $20 \mathrm{kWh} / \mathrm{m}^{2} /$ year. Cooling energy demand was reduced from 113 to 84 $\mathrm{kWh} / \mathrm{m}^{2} /$ year resulting to an energy saving of $21.7 \mathrm{kWh} / \mathrm{m}^{2} /$ year. As also expected, this is lower than savings in the Portmore case-study house which is exposed to higher ambient temperatures.

Assuming efficiency of 1 for heating (electric), $\mathrm{COP}$ of 3 for cooling and $\mathrm{CO}_{2}$ emission factor from electricity of $0.4109 \mathrm{kgCO} / \mathrm{kWh}$, potential $\mathrm{CO}_{2}$ emissions savings of $0.96 \mathrm{kgCO}_{2} / \mathrm{m}^{2} /$ year. 


\subsection{Comparison of energy reduction of cool roof and insulation}

Insulation is traditionally used to reduce heat transfer and subsequently reduce energy demand in buildings. This section presents the simulated energy reduction results of cool roof compared to roof insulation interventions for the two case-study houses.

Italy is divided into six climatic zones according to climatic conditions. For refurbished buildings in each zone maximum U-values are recommended for horizontal surfaces [4]. Palermo is located in climatic zone B and the recommended U-value is $0.32 \mathrm{~W} / \mathrm{m}^{2} \mathrm{~K}$ for refurbishments carried out from 2021. In Jamaica, the energy code [5] specifies a maximum of $1.08 \mathrm{~W} / \mathrm{m}^{2} \mathrm{~K}$ for concrete deck flat roofs. Therefore, these value were used for the comparison with cool roof.

The results of the simulations are presented in Fig. 5 and 6. As expected in Palermo during the heating period, thermal insulation has reduced energy demand from 13 to $8 \mathrm{kWh} / \mathrm{m}^{2} /$ year while cool paint has increased heating demand to $20 \mathrm{kWh} / \mathrm{m}^{2}$. Cooling demand was reduced from $113 \mathrm{kWh} / \mathrm{m}^{2} /$ year to 88 (cool paint) and 84 (insulation). Net energy demand savings are $22 \mathrm{kWh} / \mathrm{m}^{2} /$ year for cool paint and $30 \mathrm{kWh} / \mathrm{m}^{2} /$ year for insulation; therefore roof insulation is more beneficial throughout the year. In Portmore, there is no heating demand; the cooling demand is reduced by $188 \mathrm{kWh} / \mathrm{m}^{2} /$ year with the cool paint and $195 \mathrm{kWh} / \mathrm{m}^{2} /$ year with the insulation; therefore cool roof or insulation offer similar energy reduction benefits. 


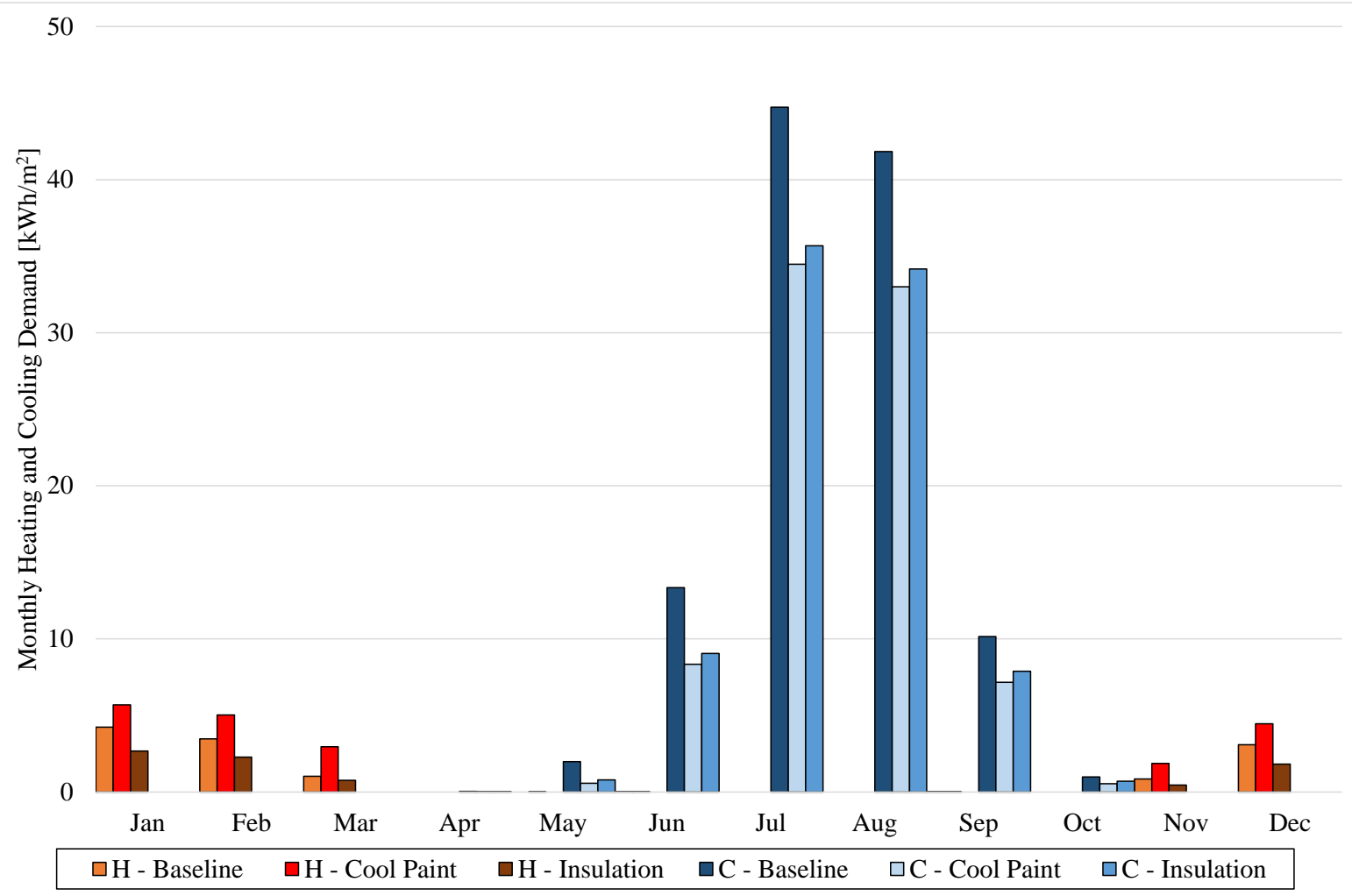

Fig. 5: Energy demand of the case-study house in Palermo for current, cool roof and roof insulation according to local guidelines.

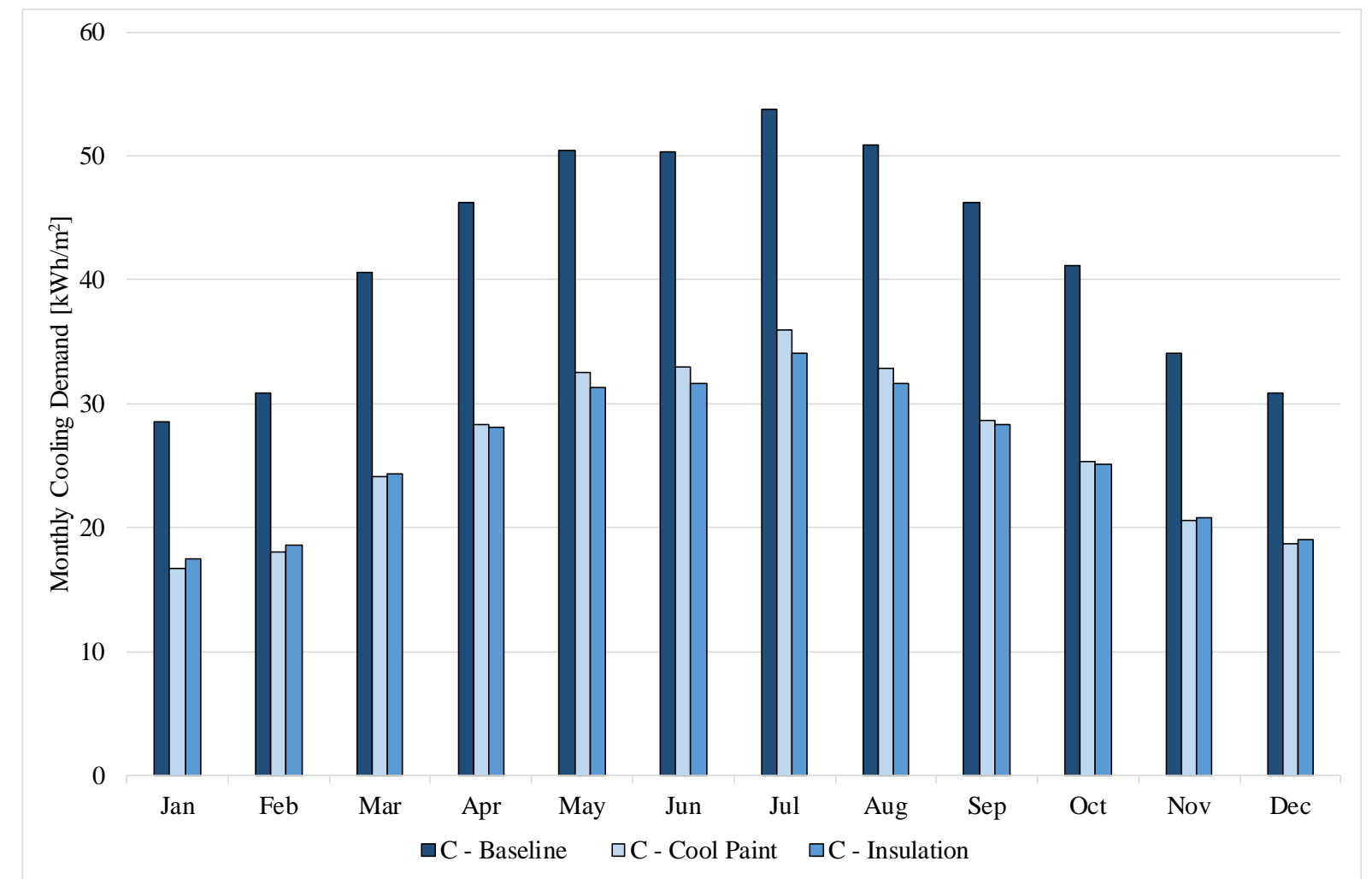

Fig. 6: Energy demand of the case-study house in Portmore for current, cool roof and roof insulation according to local guidelines. 


\section{Cool Paint LCA: methods and materials}

Section 2 presented energy demand comparison between cool roof and roof insulation interventions showing that cool roof can provide equivalent energy savings. This section presents an LCA study of the cool paint used for the case-study buildings. The LCA study of cool paint used processed-based attributional modelling following the guidelines and framework of ISO 14044/40; the study included: goal and scope definition, inventory, impact assessment and results interpretation [28-30]. The software used was SimaPro v8.2.3.0 [31] with incorporated ReCiPe 2016 environmental impact assessment method. ReCiPe 2016 (a successor of Eco-indicator 99 and CML-IA) integrates the midpoint and endpoint impact categories of both methods, in order to interpret the lifecycle environmental impact. The method converts lifecycle inventory emitted substances to 18 midpoint impact category indicators and 3 endpoint impact category indicators, by adopting the hierarchist midpoint and endpoint characterisation factors at a global scale (30, 32-34). Box 1 presents the ReCiPe 18 midpoint and 3 endpoint impact category indicators.

Box 1: midpoint and endpoint impact indicators

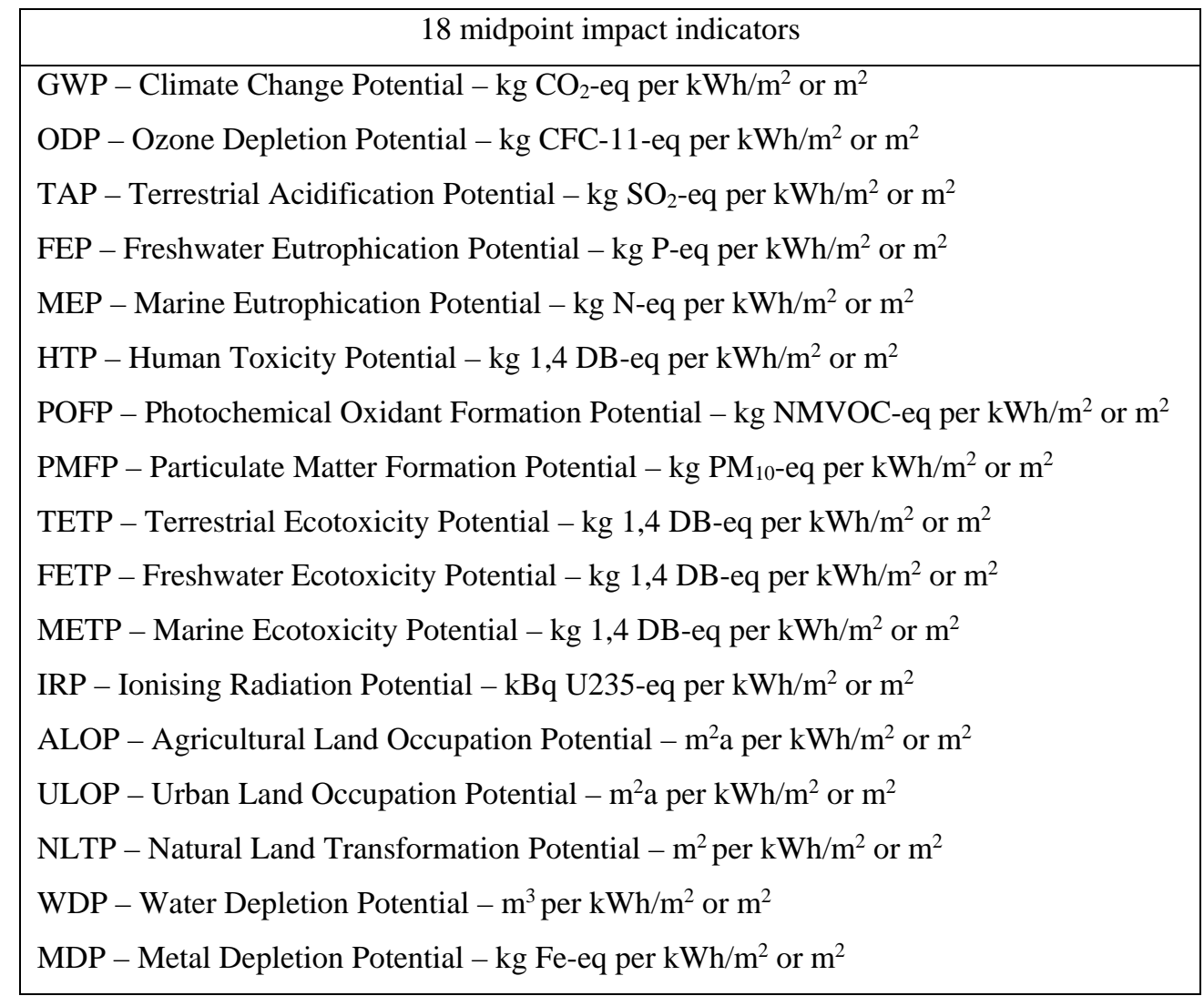




\begin{tabular}{|l|}
\hline FDP - Fossil Depletion Potential - kg oil-eq per $\mathrm{kWh} / \mathrm{m}^{2}$ or $\mathrm{m}^{2}$ \\
\hline \multicolumn{1}{|c|}{3 midpoint impact indicators } \\
\hline HHP - Human Health Potential - DALY per $\mathrm{kWh} / \mathrm{m}^{2}$ or $\mathrm{m}^{2}$ \\
EP - Ecosystem Potential - species.yr per $\mathrm{kWh} / \mathrm{m}^{2}$ or $\mathrm{m}^{2}$ \\
$\mathrm{RP}$ - Resources Potential - $€$ per $\mathrm{kWh} / \mathrm{m}^{2}$ or $\mathrm{m}^{2}$ \\
\hline
\end{tabular}

\subsection{Goal, scope and functional unit}

The goal of this LCA study were to estimate the lifecycle environmental impacts of cooling energy demand reduction by the cool paint presented in section 2.1. The scope was Cradle to Grave (CTGR) within the LCA system boundary as presented in Fig. 7. It covers:

(a) production of cool paint material/chemical inputs (including raw material acquisition),

(b) production of cool paint,

(c) transportation of cool paint material/chemical inputs to production site and

(d) transportation of cool paint material/chemical inputs to building case study site (for application)

(e) application of cool paint,

(f) maintenance over service life and

(g) waste management (from cool paint production and maintenance).

The functional units (units of analysis) for a service life of 5 years, for this study, are 1 $\mathrm{kWh} / \mathrm{m}^{2}$ of cooling energy demand reduction and $1 \mathrm{~m}^{2}$ of installed cool paint to the climate controlled space. 


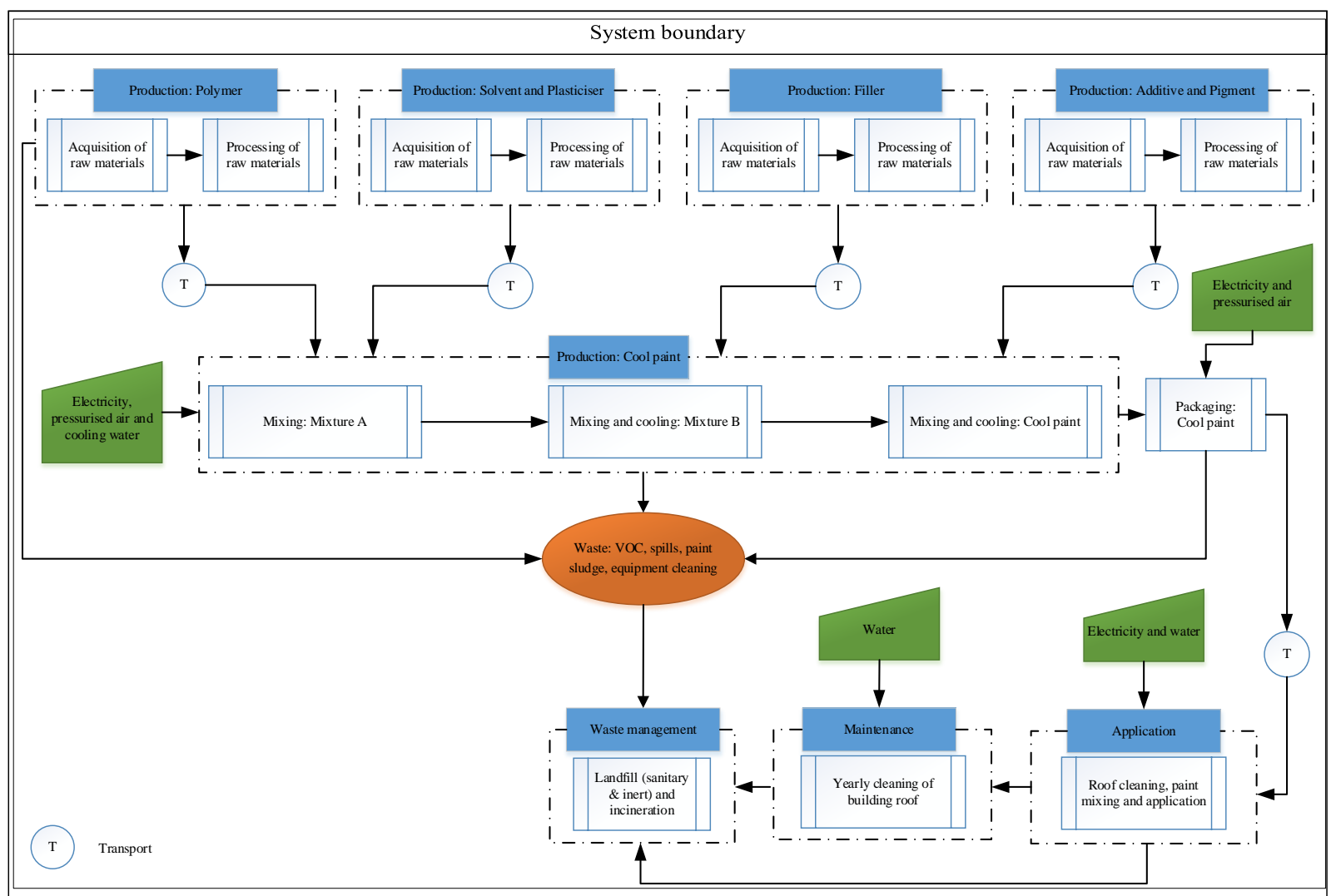

Fig. 7. The LCA system boundary for the cool paint.

\subsection{System boundary description and inventory}

Table 4 presents the Life Cycle Inventory (LCI) data (including assumptions) used for the LCA study of the cool paint. The LCI data collection based on the system boundary (Fig. 7) was classified, as follows:

i. The Foreground data - describes the LCI data that were directly sourced from the company who produced the cool paint (Table 4).

ii. The Background generic data - describes the materials, energy, transport and waste management data that were sourced from Ecoinvent via the SimaPro v8.2.3.0 software used for the LCA study [30, 35].

Specific information about the system boundary (Fig. 7) are described below. All phases are the same for both case-studies (same cool paint by the same manufacturer) apart from transportation which is different as the cool paint is produced in different factories and transported to different location. 
Table 4: Foreground inventory data for the production of cool paint.

\begin{tabular}{|c|c|c|}
\hline Material/chemical input & Value (\%) & Input composition \\
\hline \multirow[t]{2}{*}{ Polymer } & 50 & Acrylic dispersion (70 \%) \\
\hline & & Polyurethane (30 \%) \\
\hline \multirow[t]{2}{*}{ Solvent } & 20 & Water (80 \%) \\
\hline & & Glycol ethers (20 \%) \\
\hline Filler & 15 & Barite \\
\hline Pigment & 10 & Titanium dioxide \\
\hline Additive & 4 & Zinc dioxide \\
\hline Plasticiser & 1 & Phthalic Anhydride \\
\hline
\end{tabular}

\section{Production}

The material/chemical inputs to produce cool paint are polymer, solvent, plasticiser, filler, additive and pigment. The production of these material/chemical inputs considers the acquisition and processing of raw materials, which includes the consumption of raw materials (and transport), energy, infrastructure, land use and waste treatment (and transport). The specific material/chemical inputs in accordance with the functionality and properties of the cool paint were sourced from commercially available company/literature. The production process of the specific material/chemical inputs was sourced from Ecoinvent via the SimaPro v8.2.3.0 software (manufacturer).

The produced material/chemical inputs were transported to the cool paint production site, where they are chronologically mixed in accordance with the cool paint manufacturer. "Mixture A" is the mixture of dispersed polymer, solvent and plasticiser. "Mixture B" is the mixture of "Mixture A" and filler. The cool paint product was finally produced after the mixing of "Mixture B" with additives and pigments. It was assumed that the mixing was done with two shaft mixer-dispersers that requires cooling during the production of "Mixture B" and the final cool paint product. The mixing and cooling required energy, pressurised air and cooling water inputs.

\section{Application:}

The packaged cool paint was transported to the case study location where it was applied to the building roof. The building roof was prepared by cleaning the surface with water, followed by paint mixing with drill and paddle mixer, and finally the application of $1.4 \mathrm{~kg} / \mathrm{m}^{2} \mathrm{cool}$ paint with solvent resistant skin roller.

\section{Transport:}


The transportation phase of the LCA assesses the transportation impact during the supply of the six material/chemical inputs to the manufacturer site and then the produced cool paint to the case-study location site. The manufacturing was at Tocancipa, Colombias for the Jamaica case-study and Alcobendas, Spain for the Silicy case-study. The transportation during the acquisition and processing of the material/chemical inputs are embedded in the environmental impact of the production of the material/chemical inputs. The transportation modes and distances are summarised in Table 5. It was assumed that the Polymer, Solvent, Plasticiser, Filler, Additive and Pigment were acquired from a retailer/wholesaler in Bogota, Colombia, which is supplied by road to the manufacturer site. It was also assumed that the produced cool paint was transported by road from the manufacturer site to the port of Cartagena, Colombia then by sea to the port of Kingston, Jamaica and finally by road to the case study location site. For the Sicily case-study Polymer, Solvent, Plasticiser, Additive and Pigment were acquired from a retailer/wholesaler in Tarragona, Spain, while the Filler was acquired from a retailer/wholesaler in Girona, Spain, which was supplied by road to the manufacture site.

Table 5: Transportation modes and distances in the supply of all produced material/chemical inputs of cool paint and produced cool paint.

\begin{tabular}{|c|c|c|c|}
\hline Case-study & Input & Value & Transport mode \\
\hline \multirow[t]{4}{*}{ Jamaica } & Material/chemical to manufacturing site & $40 \mathrm{~km}$ & Lorry $(3.5-7.5 \mathrm{t})$ \\
\hline & Packaged cool paint to case-study site & $1078 \mathrm{~km}$ & Lorry $(3.5-7.5 \mathrm{t})$ \\
\hline & & $854 \mathrm{~km}$ & Transoceanic ship \\
\hline & & $8 \mathrm{~km}$ & Lorry $(3.5-7.5 \mathrm{t})$ \\
\hline \multirow[t]{4}{*}{ Sicily } & Material/chemical to manufacturing site & $1254 \mathrm{~km}$ & Lorry $(3.5-7.5$ t) \\
\hline & Packaged cool paint to case-study site & $377 \mathrm{~km}$ & Lorry $(3.5-7.5 \mathrm{t})$ \\
\hline & & $1287 \mathrm{~km}$ & Transoceanic ship \\
\hline & & $20 \mathrm{~km}$ & Lorry $(3.5-7.5 \mathrm{t})$ \\
\hline
\end{tabular}

\section{Maintenance:}

The roof is manually cleaned annually with water to remove accumulated dirt. It was assumed that $1.4 \mathrm{~kg} / \mathrm{m}^{2}$ of water was used per year for the service life of 5 years.

\section{Waste management:}

The waste management involves landfill and incineration of waste from the production of polymer, solvent, plasticiser, filler, additive, pigment, production and packaging of cool paint, application and end of life (assuming the building was demolished and landfilled; this only considers landfilling of the cool paint). The waste management process was sourced from Ecoinvent via the SimaPro v8.2.3.0 software. 
The most relevant lifecycle stages [36, 37] are those that contribute over $80 \%$ (starting from the largest to the smallest contributions; before normalisation and weighting) to any of the baseline impact category indicators, while the hotspot at lifecycle stages are those that cumulatively contribute at least $50 \%$ to any of the baseline impact category indicators. Therefore, results presented in the following section are those that contribute over $80 \%$ while hotspot are identified when the contribution is cumulatively more than $50 \%$.

\section{Cool paint LCA results and discussion}

\subsection{Midpoint and endpoint environmental impact category indicators and identification of hotspots}

Table 6 presents the results of the midpoint environmental impacts per $\mathrm{m}^{2}$ of applied paint and $\mathrm{kWh} / \mathrm{m}^{2}$ of cooling demand for Jamaica and Sicily. It can be seen that the impact indicators differ slightly for the two cases mainly because of transportation. Fig. 8 and 9 present the percentage contribution of the midpoint environmental impacts while Fig. 10 presents the percentage contribution of the endpoint environmental impacts.

The main difference between the endpoint environmental impacts of the cool paint in Jamaica and Sicily is solely due to impacts from the transport of the cool paint to the building application site.

At the midpoint impact category level as shown in Fig. 8 and 9, the production of polymer and pigment and transport are the main contributors to 12 impact category indicators: GWP, FEP, ODP, TAP, MEP, POFP, PMFP, IRP, ULOP, NLTP, MDP and FDP. The production of polymer and pigment and waste management are the main contributors to the HTP, FETP and METP. The production of polymer and pigment are the main contributors to MEP. The main contributors to ALOP and WDP are production of polymer, pigment and cool paint.

Therefore at midpoint level across the 18 environmental midpoint impact category indicators, the acquisition and processing of raw materials (contributed by production of polymer (45 \%), production of pigment (20\%), production of cool paint (7\%) and transport (15\%) are the most relevant lifecycle stages contributing over $80 \%$ of the environmental impacts.

At the endpoint level as shown in Fig. 10 the production of polymer and pigment and transport are the main contributors to the EP and RP while the main contributors to HHP are the same plus waste management. Therefore at the endpoint level, the acquisition and 
processing of raw materials are the identified hotspots, contributing at least $50 \%$ of the environmental impacts. The production of polymer contribution to the environmental impacts are mostly due to the acquisition and processing of $\mathrm{TiO}_{2}$, acrylic binder, Toluene diisocyanate and polyol, which are the raw materials used for its production. The contribution by the production of pigment is mostly due to the acquisition and processing of $\mathrm{TiO}_{2}$.

Across the three environmental endpoint impact category indicators, the acquisition and processing of raw materials (production of polymer (49\%) and production of pigment (18\%)), production of cool paint $(6 \%)$ and transport $(16 \%)$ are the most relevant lifecycle stages contributing over $80 \%$ of the environmental impacts.

In conclusion, across all the midpoint and endpoint environmental impacts, the identified hotspots contributing at least $50 \%$ of the environmental impacts are acquisition and processing of raw materials.

Table 6: Midpoint cradle to grave environmental impacts of cool paint in Jamaica and Sicily

\begin{tabular}{|c|c|c|c|c|}
\hline $\begin{array}{l}\text { Impact } \\
\text { indicators }\end{array}$ & $\begin{array}{l}\text { per } 1 \mathrm{~m}^{2} \\
\text { Jamaica }\end{array}$ & $\begin{array}{l}\text { per } 1 \mathrm{~m}^{2} \\
\text { Sicily }\end{array}$ & $\begin{array}{l}\text { per } 1 \mathrm{kWh} / \mathrm{m}^{2} \\
\text { Jamaica }\end{array}$ & $\begin{array}{l}\text { per } 1 \mathrm{kWh} / \mathrm{m}^{2} \\
\text { Sicily }\end{array}$ \\
\hline GWP & 5.04 & 4.92 & 0.0265 & 0.0259 \\
\hline ODP & 0.000000469 & 0.000000448 & 0.00000000247 & 0.00000000236 \\
\hline TAP & 0.0260 & 0.0259 & 0.000137 & 0.000136 \\
\hline FEP & 0.00154 & 0.00153 & 0.00000810 & 0.00000803 \\
\hline MEP & 0.00175 & 0.00175 & 0.00000922 & 0.00000919 \\
\hline HTP & 2.79 & 2.75 & 0.0147 & 0.0145 \\
\hline POFP & 0.0168 & 0.0166 & 0.0000884 & 0.0000875 \\
\hline PMFP & 0.0119 & 0.0118 & 0.0000626 & 0.0000620 \\
\hline TETP & 0.000817 & 0.000782 & 0.00000430 & 0.00000412 \\
\hline FETP & 0.0858 & 0.0850 & 0.000452 & 0.000447 \\
\hline METP & 0.0815 & 0.0805 & 0.000429 & 0.000424 \\
\hline IRP & 0.361 & 0.352 & 0.00190 & 0.00185 \\
\hline ALOP & 0.294 & 0.292 & 0.00155 & 0.00154 \\
\hline ULOP & 0.0736 & 0.0693 & 0.000387 & 0.000365 \\
\hline NLTP & 0.000948 & 0.000903 & 0.00000499 & 0.00000475 \\
\hline WDP & 0.16 & 0.16 & 0.000843 & 0.000841 \\
\hline MDP & 0.219 & 0.212 & 0.00115 & 0.00112 \\
\hline FDP & 1.64 & 1.60 & 0.00865 & 0.00843 \\
\hline
\end{tabular}




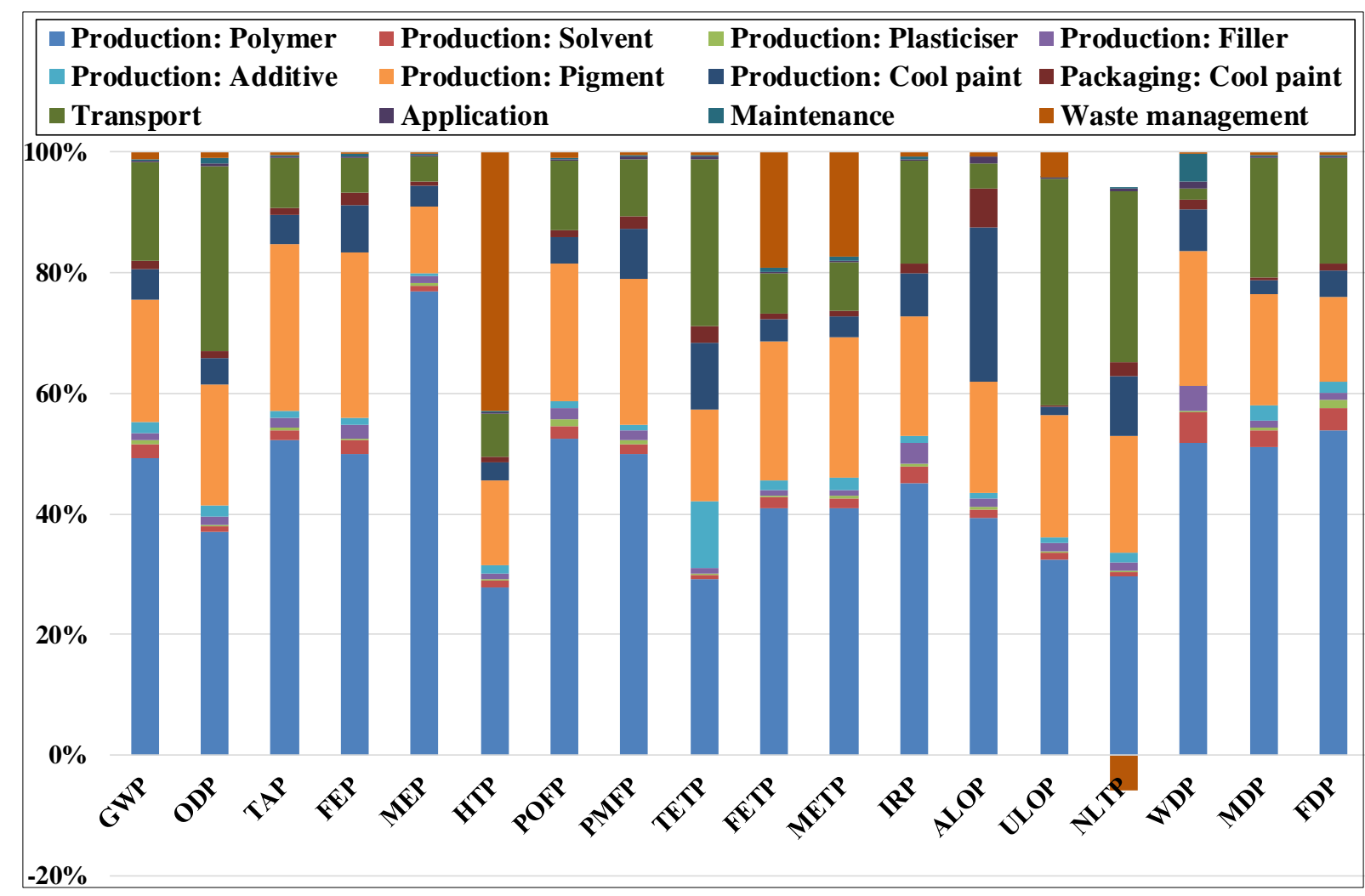

Fig. 8. Midpoint percentage contribution by the lifecycle phases of the cool paint in Jamaica.

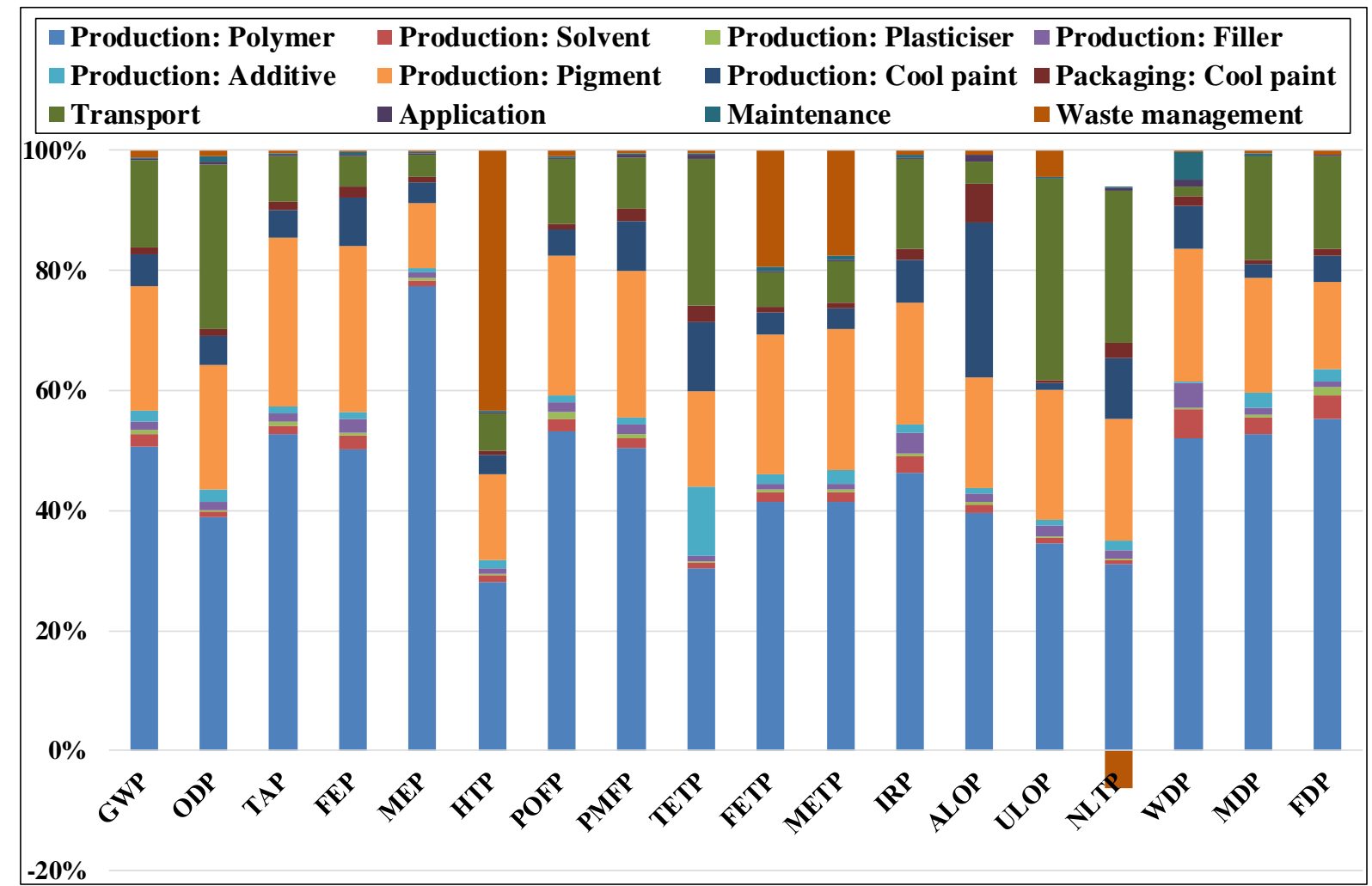

Fig. 9. Midpoint percentage contribution by the lifecycle phases of the cool paint in Sicily. 


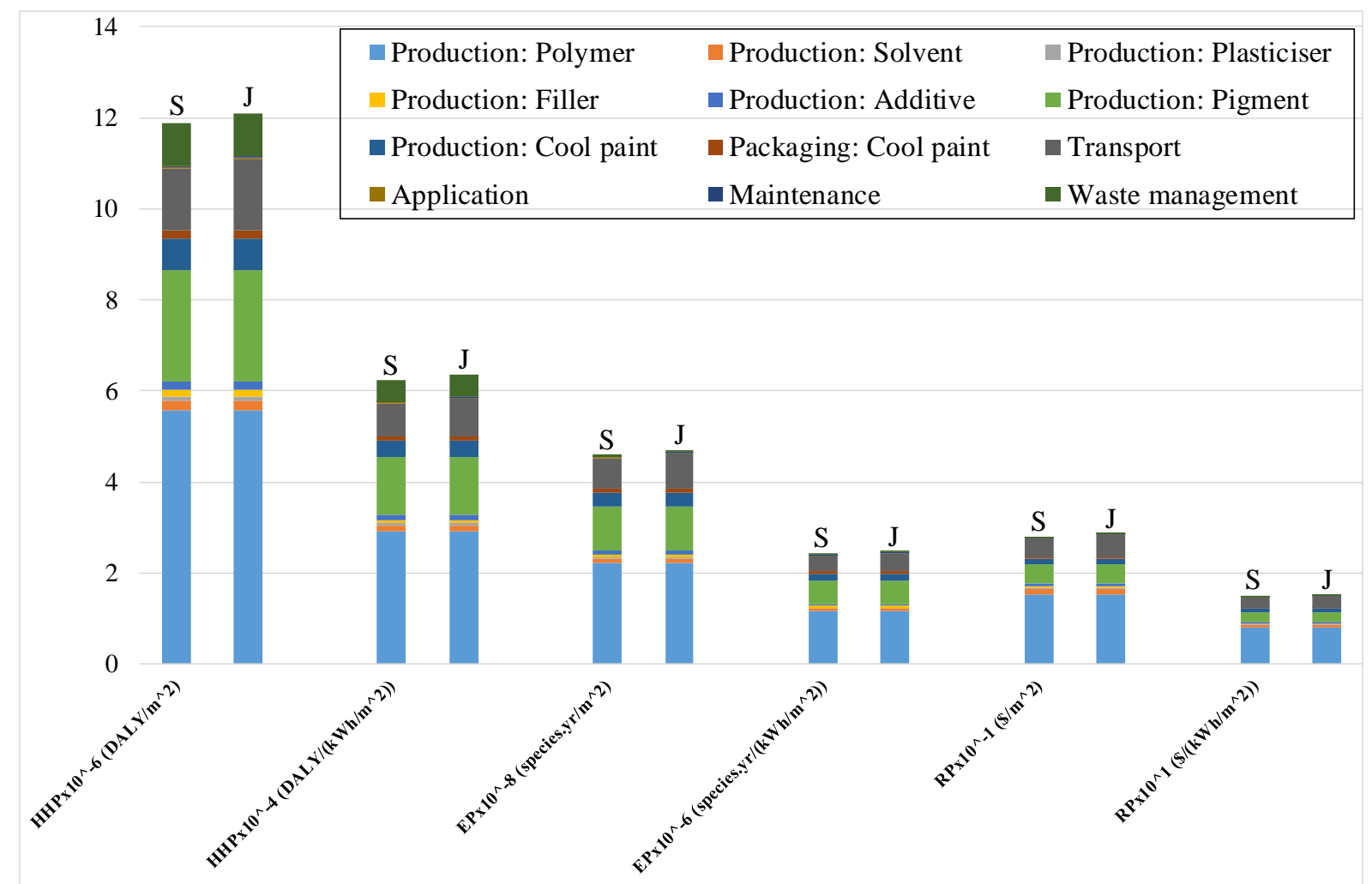

Fig. 10. Endpoint lifecycle impacts of the cool paint in Sicily (S) and Jamaica (J).

\subsection{Comparison with LCA studies of insulation materials}

In this section, the environmental impact of cool paint is compared to literature studies of environmental impact of insulation materials. Cradle to Gate (CTGA; raw material acquisition and production) and Cradle to Site (CTSI; raw material acquisition and production, transportation to the building site and installation) approaches were used for the comparison. CTGA and CTSI were used depending on the available data in the literature for thermal insulation.

Table 7 presents the CTGA GWP and TAP of the cool paint compared with the CTGA of the RockWool (RW), Expanded Polystyrene (EPS) and Wood Fibre (WF) for wall and/or roof of low-rise buildings in Central Europe [38]. It also compares CTGA GWP, ODP, POFP, TEP, FEP, MEP and WDP of the cool paint compared with the CTGA of EPS, Mineral Wool (MW) and Phenolic Foam (PF) [39]. Table 8 presents the CTSI GWP, ODP and TAP of the cool paint compared with the CTSI of the Extruded Polystyrene (XPS), Expanded Polystyrene (EPS), Polyurethane (PU), Stone Wool (SW) and Spray Foam (GW) in Spain [40].

Žigart et al [38] studied different external wall elements (structural materials, thermal insulation materials and surface finishing) for different types of constructions. Therefore, the average GWP and TAP contribution by the studied thermal insulations were calculated according to the stated percentage share stated for thermal insulations. As a result, the GWP 
and TAP of the cool paint were 4 to 7 -fold and 6 to 17-fold lower, than all of the thermal insulation materials.

It has been found [39] that the GWP, ODP, FEP, MEP and POFP of the cool paint were similar and up to 9-fold lower than EPS, MW and PF, while the WDP of the cool paint is 4 to 26-fold higher. The main contributing emission substances by cool paint to GWP are $\mathrm{CO}_{2}$ (90 $\%)$ and methane $\left(\mathrm{CH}_{4} ; 9 \%\right)$, while sulphur dioxide $\left(\mathrm{SO}_{2}\right)(76 \%)$ and nitrogen oxides $\left(\mathrm{NO}_{\mathrm{x}}\right)$ (23\%) are the contributing substances to TAP. Similarly, the contributing emission substances by the thermal insulations to GWP are $\mathrm{CO}_{2}$ and $\mathrm{CH}_{4}$, while $\mathrm{SO}_{2}$ and $\mathrm{NO}_{\mathrm{x}}$ are the contributing substances to TAP. The higher (mostly) or lower environmental impact category indicators of the thermal insulations compared to the cool paint is probably because of the production phase; insulator materials with high material density has a high environmental impact due to high primary energy demand during the acquisition (which includes transportation) and processing of raw materials.

The TAP of the cool paint has been found [40] to besimilar and up to 6.5-fold lower than all thermal insulation materials, GWP were 2 to 3-fold lower than XPS and EPS, and 40\% and up to 2-fold higher than PU, SW and GW, while ODP were similar and up to 7-fold lower than XPS, EPS and SW, and up to 77 \% higher than XPS, PU and GW.

The midpoint environmental impact indicators of the cool paint from this study were compared with the results reported in the literature that investigated the midpoint environmental impact of insulation materials. The average values of the study of [38] were reported in Table 7 because different U-values of insulation construction were assessed. From the comparison presented in Tables 7 and 8 , it can be seen that the CTGA/CTSI/CTGR environmental impacts of the cool paint are lower than insulation materials. The higher CTGA/CTSI/CTGR environmental impact of insulation materials is mainly due to the fossil fuel consumption required during the production phase, which includes raw material acquisition and processing. 
Table 7: Midpoint cradle to gate environmental impacts (per $1 \mathrm{~m}^{2}$ ) comparison of cool paint with thermal insulation materials.

\begin{tabular}{|c|c|c|c|c|c|c|c|}
\hline \multirow[t]{2}{*}{$\begin{array}{l}\text { Impact } \\
\text { indicators }\end{array}$} & \multirow{2}{*}{$\begin{array}{l}\text { This study } \\
\text { Cool paint } \\
\text { Sicily }\end{array}$} & \multicolumn{3}{|c|}{$\begin{array}{l}\text { Central Europe case study (U- } \\
\left.\text { value }=0.25 \mathrm{~W} / \mathrm{m}^{2} \mathrm{~K}\right)\end{array}$} & \multicolumn{3}{|c|}{$\begin{array}{l}\text { UK case study location (U-value }=0.33 \\
\mathrm{~W} / \mathrm{m}^{2} \mathrm{~K} \text { ) }\end{array}$} \\
\hline & & RW & EPS & WF & EPS & MW & $\mathrm{PF}$ \\
\hline$\overline{\text { GWP }}$ & 4.13 & 32.2 & 16.9 & 19.4 & 14.4 & 15.5 & 17.1 \\
\hline ODP & 0.000000314 & & & & 0.000000451 & 0.000000760 & 0.000000715 \\
\hline TAP & 0.0236 & 0.404 & 0.16 & 0.261 & & & \\
\hline FEP & 0.00143 & & & & 0.0016 & 0.0055 & 0.00470 \\
\hline MEP & 0.00167 & & & & 0.0087 & 0.015 & 0.011 \\
\hline POFP & 0.0146 & & & & 0.079 & 0.052 & 0.085 \\
\hline WDP & 0.147 & & & & 0.0056 & 0.0230 & 0.0320 \\
\hline
\end{tabular}

Table 8: Midpoint cradle to site environmental impacts (per $1 \mathrm{~m}^{2}$ ) comparison of cool paint with thermal insulation materials

\begin{tabular}{|c|c|c|c|c|c|c|}
\hline \multirow[t]{2}{*}{ Impact indicators } & \multirow{2}{*}{$\begin{array}{l}\text { This study } \\
\text { Cool paint } \\
\text { Sicily }\end{array}$} & \multicolumn{5}{|c|}{ Spain case study (U-value $=0.25 \mathrm{~W} / \mathrm{m}^{2} \mathrm{~K}$ ) } \\
\hline & & XPS & EPS & $\mathrm{PU}$ & SW & GW \\
\hline GWP & 4.84 & 8.50 & 14.0 & 11.0 & 2.10 & 3.90 \\
\hline ODP & 0.000000439 & 0.000000460 & 0.000000680 & 0.00000011 & 0.0000032 & 0.0000003 \\
\hline TAP & 0.0257 & 0.03 & 0.0460 & 0.046 & 0.17 & 0.032 \\
\hline
\end{tabular}

\section{Conclusion}

A cool roof applied as a retrofit to two low rise detached houses in the islands of Sicily and Jamaica was studied. Simulation results using EnergyPlus models calibrated with measurements from the houses show that potential energy savings are $21.7 \mathrm{kWh} / \mathrm{m}^{2} /$ year for the house in Silicy and $188 \mathrm{kWh} / \mathrm{m}^{2} /$ year for Jamaica. This indicates the high energy savings potential in more poorly insulated roofs in locations with high solar radiation throughout the year and high ambient temperatures. It also shows that it is a worthwhile retrofit options in locations with high solar radiation but also some heating demand.

The cool roof energy savings were compared with savings due to insulation according to the local guidelines $\left(0.32 \mathrm{~W} / \mathrm{m}^{2} \mathrm{~K}\right.$ in Silicy and $1.08 \mathrm{~W} / \mathrm{m}^{2} \mathrm{~K}$ in Jamaica). The simulation results show that energy savings by cool roof or insulation are similar in Jamaica (188 $\mathrm{kWh} / \mathrm{m}^{2} /$ year with the cool paint and $195 \mathrm{kWh} / \mathrm{m}^{2} /$ year with the insulation) while the heating penalty in Sicily results to higher energy savings with insulation $\left(22 \mathrm{kWh} / \mathrm{m}^{2} /\right.$ year for cool paint and $30 \mathrm{kWh} / \mathrm{m}^{2} /$ year for insulation). This is also influenced by the low U-value of roof insulation in Sicily. 
The use of LCA to estimate lifecycle environmental impact category indicators of the cool paint shows that the production of polymer and pigment lifecycle phase are the main hotspots responsible for most environmental impacts at both midpoint (45\% polymer and $20 \%$ pigment) and endpoint (49\% polymer and $18 \%$ pigment) categories. The contribution to the environmental impacts are mostly due to the acquisition and processing of raw materials for the production of the material/chemical inputs. The comparison of the findings from this study with results reported in the literature found that the lifecycle environmental impacts of the cool paint are lower than insulation materials.

It can be concluded that a cool roof is an attractive low cost retrofit solution for the reduction of energy demand in low rise residential buildings also offering reduced environmental impact compared to insulation materials. Further work will investigate the balance of heating/cooling demand and thermal insulation as well as retrofit costs for various climatic conditions.

\section{Acknowledgement}

This work is supported by SMART GEMS (H2020-MSCA-RISE-2014 (GA No 645677)) and EPSRC DTP of Brunel University London.

\section{List of References}

1. Cool Roof Rating Council, US. https://coolroofs.org/ (accessed 17 Jan 2020).

2. European Cool Roofs Council, EU. https://coolroofcouncil.eu/ (accessed 17 Jan 2020).

3. California Energy Commission (2018). Building Energy Efficiency Standards for Residential and NonResidential Buildings, Title 24, Part 6, and associated administrative regulations in part 1. https://ww2.energy.ca.gov/2018publications/CEC-400-2018020/CEC-400-2018-020-CMF.pdf (accessed 17 Jan 2020).

4. Decreto interministeriale 26 giugno 2015, Allegato 1, par.2.3, comma 3, https://www.mise.gov.it/index.php/it/normativa/decreti-interministeriali/2032968decreto-interministeriale-26-giugno-2015-adeguamento-linee-guida-nazionali-per-lacertificazione-energetica-degli-edifici (accessed 17 Jan 2020).

5. JS 309, (2019), Jamaica Application Document for the International energy conservation code, Bureau of Standards Jamaica.

6. Santamouris M (2014). Cooling the cities - A review of reflective and green roof mitigation technologies to fight heat island and improve comfort in urban environments, Solar Energy Vol 103, pp 682-703 
7. Testa J and Krarti M (2017). A review of benefits and limitations of static and switchable cool roof systems, Renewable and Sustainable Energy Reviews, Vol 77, pp 451-460

8. Pisello A L, (2017). State of the art on the development of cool coatings for buildings and cities, Solar Energy, Vol 144, pp 660-680

9. Synnefa A and Santamouris M, (2012). Advances on technical, policy and market aspects of cool roof technology in Europe: The Cool Roofs project, Energy and Buildings, Vol 55, pp 35-41

10. Gao Y, Xu J, Yang S, Tang X, Zhou Q, Ge J, Xu T, and Levinson R, (2014). Cool roofs in China: policy review, building simulations, and proof-of-concept experiments, Energy Policy, pp. 190-214

11. Radhi H, Sharples S, Taleb H and M. Fahmy M (2017).Will cool roofs improve the thermal performance of our built environment? A study assessing roof systems in Bahrain Energy \& Buildings, Vol 135 pp. 324-337

12. Garg V, Kotharkar R, Sathaye J, Rallapalli H, Kulkarni N, Reddy N, Rao P and Sarkar A (2016). Assessment of the impact of cool roofs in rural buildings in India Energy \& Buildings, Vol 114 pp. 156-163

13. Dabaieh M, Wanas O, Hegazy M A and Johansson E (2015). Reducing cooling demands in a hot dry climate: A simulation study for non-insulated passive cool roof thermal performance in residential buildings, Energy and Buildings Vol 89, pp 142-152

14. Kolokotroni M, Shittu E, Santos T, Ramowski L, Mollard A, Rowe K, Wilson E, de Brito Filho J, Novieto D (2018). Cool Roofs: High Tech Low Cost solution for energy efficiency and thermal comfort in low rise low income houses in high solar radiation countries, Energy and Buildings Vol 176, pp 58-70

15. Kolokotroni M, Wines C, Babiker R M A and Hartmann Da Silva B (2016). Cool and Green Roofs for Storage Buildings in Various Climates, Procedia Engineering, Vol 169, pp 350-358

16. Hosseini M and Akbari H (2014). Heating energy penalties of cool roofs: the effect of snow accumulation on roofs, Advances in Building Energy Research Journal , Vol 8, pp $1-13$

17. Tong S and Li H, (2017) Life-cycle cost analysis of roofing technologies in tropical areas, Energy and Buildings Vol 151 pp 283-292

18. Shi D, Gao Y, Guo R, Levinson R, Sun Z and Li B (2019). Life cycle assessment of white roof and sedum-tray garden roof for office buildings in China, Sustainable Cities and Society, Vol 46 
19. Cubi E, Zibin N F, Thompson S J and Bergerson J (2015). Sustainability of Rooftop Technologies in Cold Climates: Comparative Life Cycle Assessment of White Roofs, Green Roofs, and Photovoltaic Panels, Journal of Industrial Tehcnology.

20. Pushkar S and Verbitsky O (2017) Life Cycle Assessments of white flat and red or white pitched roofs for residential buildings in Israel. Journal of Green Building: Vol. 12, No. 2, pp. 95-111.

21. EPA, (1992). Control of VOC emissions from ink and paint manufacturing processes.

22. Onyenekenwa C E, (2016). A guide for the paint maker.

23. Meteonorm, https://meteonorm.com/en/ (accessed 17 Jan 2020)

24. EnergyPlus ${ }^{\mathrm{TM}}$ Documentation, Engineering Reference, The Reference to EnergyPlus Calculations available online:

https://energyplus.net/sites/all/modules/custom/nrel_custom/pdfs/pdfs_v9.2.0/Engineerin gReference.pdf (accessed 17 Jan 2020)

25. CIBSE Guide A (2015): Environmental Design, CIBSE, UK

26. Watkins R, Palmer J, Kolokotroni M and Littlefair P, (2002). The London Heat Island results from summertime monitoring, Proc. Chartered Institution of Building Services Engineers, Series A, Building Services Engineering Research \&Technology, Vol (23). No 2 pp97-106.

27. U.S. Department of Energy, (2015). M \& V Guidelines: Measurement and Verification for Performance-Based Contracts Version 4.0 1-306

28. BS EN ISO, (2018). Environmental management - Life cycle assessment - Requirements and guidelines.

29. BS EN ISO, (2006). Environmental management - Life cycle assessment - Principles and framework.

30. PRé, Goedkoop M, Oele M, Leijting J, Ponsioen T, and Meijer , (2016). Introduction to LCA with SimaPro. https://www.presustainability.com/download/SimaPro8IntroductionToLCA.pdf (accessed 17 Jan 2020).

31. PRé, (2016). SimaPro Database Manual; Methods Library. https://doi.org/10.1017/CBO9781107415324.004

32. Huijbregts M A J, Steinmann Z J N , Elshout P M F, Stam G, Verones F, Vieira M, Zijp M, Hollander A, and van Zelm R. (2017). ReCiPe2016: a harmonised life cycle impact assessment method at midpoint and endpoint level. International Journal of Life Cycle Assessment 22, 138-147. https://doi.org/10.1007/s11367-016-1246-y.

33. Huijbregts M A J, Steinmann Z J N, Elshout P M F, Stam G, Verones F, Vieira M D M, 
Hollander A, Zijp M, and vanZelm R, (2017). ReCiPe 2016 v1.1 A harmonized life cycle impact assessment method at midpoint and endpoint level Report I: Characterization. https://www.rivm.nl/en/life-cycle-assessment-lca/downloads (accessed 19 December 2018).

34. RIVM, 2018. LCIA: The ReCiPe Model. https://www.rivm.nl/en/life-cycle-assessmentlca/recipe (accessed 13 March 2019).

35. Steubing B, Wernet G, Reinhard J, Bauer C, Moreno-ruiz E, (2016). The ecoinvent database version 3 ( part II ): analyzing LCA results and comparison to version 2. The International Journal of Life Cycle Assessment 3, 1269-1281. https://doi.org/10.1007/s11367-016-1109-6.

36. European Commission, (2016). Product Environmental Footprint Pilot Guidance Guidance for the implementation of the EU Product Environmental Footprint (PEF) during the Environmental Footprint (EF) pilot phase - version 5.2 (pp. 95). http://ec.europa.eu/environment/eussd/smgp/pdf/Guidance_products.pdf (accessed 29 March 2019).

37. Zampori L, Saouter E, Schau E, Cristobal J, Castellani V and Sala S, (2016). Guide for interpreting life cycle assessment result. Eur 28266 En 60. https://doi.org/10.2788/171315.

38. Žigart M, Kovačič Lukman R, Premrov M, and Žegarac Leskovar V, (2018). Environmental impact assessment of building envelope components for low-rise buildings. Energy 163, 501-512. https://doi.org/10.1016/j.energy.2018.08.149.

39. Densley Tingley D, Hathway A and Davison B, (2015). An environmental impact comparison of external wall insulation types. Building and Environment 85, 182-189. https://doi.org/10.1016/j.buildenv.2014.11.021.

40. Sierra-Pérez J, Boschmonart-Rives J and Gabarrell X, (2016). Environmental assessment of façade-building systems and thermal insulation materials for different climatic conditions. Journal of Cleaner Production 113, 102-113. https://doi.org/10.1016/j.jclepro.2015.11.090. 